\title{
An Assessment of the Extent of Integration, Application and Utilization of Web-Based Learning Systems in Post Basic Institutions in Nigeria
}

\author{
Olaniyi Alaba Sofowora, $\mathrm{PhD}$ \\ Department of Educational Technology, Faculty of Education \\ Obafemi Awolowo University, Ile-Ife, Osun State, Nigeria \\ E-mail: oasofowora@oauife.edu.ng, oasofowora@yahoo.com
}

Received: September 19, 2011

Accepted: October 31, $2011 \quad$ Published: March 1, 2012

doi:10.5539/ass.v8n3p317

URL: http://dx.doi.org/10.5539/ass.v8n3p317

\begin{abstract}
This study employed descriptive survey design. It discussed the adoption of, and integration of Web-Based Learning Systems(WBLS) into teaching and learning for distance learning and full time students. It also discussed various concerted efforts at integrating web-based learning into the teaching and learning of Science and Technology Education at the Post-Basic Institutions (STEP-B). The specific objectives of this study are to:

(i) investigate WBLS adoption and usage among the students of Obafemi Awolowo University, Ile-Ife for both distance and residential learning,(ii) determine the availability and adequacy of the facilities / infrastructures for WBLS,(iii) assess the level of implementation of WBLS

(iv) determine the WBL format adopted by the University,(v) find out student's acceptance to use the type of WBL format adopted, and (vi)investigate the challenges facing the integration and utilization of WBLS .

The study sample consisted of two hundred and fifty undergraduate students and fifty six staff selected from OAU Ife. The research instrument is made of 35 items divided into 5 sections. The results showed that adoption and usage of WBLS in OAU Ife was very high. WBLS facilities and infrastructure are inadequate for both full time and distance learners. The students were enthusiastic to accept and use the new WBLS (Academic Blackboard and Multi-site teaching using the blended learning approach). The major challenges as ranked by the students are: techno-phobia, band width problem, epileptic power supply and insufficient infrastructure.
\end{abstract}

Keywords: Web-based learning system, Motivation, Integrated technology, Millennium Development Goals (MDGs) ICT-driven, Globalization, Open-Distance Education (O-Del)

\section{Background}

The major concern all over the universe today is how to provide quality education to all. This concern is reflected in the United Nations Declaration, Education For All (UNESCO 1990) and the Millennium Development Goals (OECD 2007). The interest in provision of quality education and the shift of interest to Information and Communication Technologies are not contradictory. This shift is necessary because both ICTs and education are important agents of globalization and economic development (Monahan 2005). It is therefore not surprising to see that the major concern today is about how to use ICTs to strengthen education and to provide a better world. Nigeria as one of the developing countries is not left out of the move to ensure self sufficiency in a highly competitive economy, based on the technologies. To achieve this, Nigeria came up with a National Policy on Information Technology (2000). According to the strategic objectives:

- ICTs are to be used for education,

- create wealth, poverty eradication and to create job opportunities (Egwu 2009),

To achieve the above, it was clearly stated in the new strategic plan on education that education at all levels would be restructured to respond to the challenges and the imagined impact of ICTs. It was also stated that ICTs will be integrated into the mainstream of education and training. It was based on the above that the Federal 
Ministry of Education came up with a roadmap on education in Nigeria. Other objectives to be achieved that are relevant to this study are:

- strengthen and expand e-learning to provide more access to quality education,

- restructure teaching and learning environment to be ICTs -driven , and

- integrate ICTs into school's curriculum right from the primary schools.

Today, there is greater demand for quality education in Nigeria than ever before. This is because of the need to resolve the challenges brought by the neglect of the youths who constituted the majority of the Nigerian population. The neglect has led to the formation of insurgent youths and miscreants such as the Gboko -Haram, the Almajiris in the Northern part of Nigeria and the Niger-Delta Youths in South-South Geo-political Zone. The Gboko- Harams are group of educationally disadvantaged youths who are opposed to western education and have caused several unimagined destructions to the growth, development and economy of the country. Not only this, their activities have given the country a very bad image as a terrorist country.

In order to bring education to the doorsteps of those who could not get it and are qualified, the country decided to use ICTs as an effective and sustainable tool. ICTs were also adopted to unlock the doors of opportunity, skill acquisition, training and rehabilitation, borrowing a leave from Kofi-Anan (2005). Obafemi Awolowo University, Ile-Ife, among other Nigerian universities, took the giant step at integrating and applying ICTs for development. The University came up with its own ICT Strategic Plan that led to the expansion of the computer network (OAUNET) for regional and collaborative research development (Ajayi, 1996).It was embarked upon as a result of the need to improve teaching and learning, provide better qualitative education to qualified youths who could not gain admission due to lack of space through open distance learning (O-Del). The adoption of WBLS in the university was therefore welcomed with mixed feelings. Several enlightment programmes were embarked upon that incorporated all the stake holders in the university. This was carried out to encourage all the stake holders to utilize this new innovation in solving work place problems and to enrich teaching and learning. It is against this background that the present study was conceived, to investigate students' acceptance, motivation and intention to use the new Web -Based Learning System in Obafemi Awolowo University, Ile-Ife.

\section{Specific Objectives of the Study}

The specific objectives of the study therefore are to:

(i) investigate the extent of the use of Web- Based Learning System among OAU students in Ile-Ife,

(ii) examine students' behavioral intention to use WBLS from a motivation point of view,

(iii) find out the level of students' acceptance

(iv) find out the challenges/problems the students are facing in utilizing WBLS .

\section{Research Methodology}

The study employed survey design. The population for the study is made up of all the students of Obafemi Awolowo University, Ile-Ife .The sample were selected from four Faculties, they are:

[i] Education.

[ii] Science

[iii] Arts

[iv] Environmental Design and Management(EDM).

Three hundred and six participants were selected, using stratified sampling procedure based on gender, course of study, Departments and Faculties. Only one structured questionnaire was developed and used for data collection. It was termed 'SAMWBLS'. It solicited for information on students' acceptance, motivation and intention to use Web- Based Learning System. It was divided into five sections. The first section measured the demography of the students and usage, section ii solicited for information on faculties and equipment, section iii examined the WBLS format adopted in OAUIfe while section iv investigated level of utilizing WBLS among OAU students. The last section, section $v$ measured attitude and challenges faced by the students. The instrument was validated, using Duncan test and content validity. A reliability of O.67 was obtained. The questionnaire was rated on five point Likert scale [from strongly agreed to strongly disagreed]

The data collected was analyzed using mean, standard deviation and Friedman Ranking Test. 


\section{Findings and Discussion}

The results of the findings in respect of the objectives are discussed

The results obtained showed that the Web-Based Learning format the students adopted are:

(i) e-learning format (70.8\%) while $22.5 \%$ did not like e-learning format

(ii) for multi-media learning (68\%) enjoyed using the format while $25.1 \%$ dislike the format and $(6.9 \%)$ are indifferent.

(iii) With respect to tele-lecture $68.6 \%$ are in favour, $11 \%$ not in favour while $20.3 \%$ were skeptical about its usage.With regards to blended technology $66.6 \%$ agreed to utilize this format, $11 \%$ were not favourably disposed to using it. (See Table 1)

However when it comes to video-taped instruction and CD ROM the number of students in favour are higher $68.3 \%$ while $27.8 \%$ are not in favour and $4.1 \%$ undecided. From the above data, it appeared that more students are actually interested in using non web-based learning system. This may not be unconnected with the availability of infrastructure and internet facilities that limits its utilization. With respect to the factors that motivated the students to use the WBLS find the results obtained in Table 2.

The factors that motivated the students to wanting to utilize these learning formats are: the ability of the new system to reduce the problem of large classroom and overcrowding. $91.5 \%$ agreed, $4.9 \%$ disagreed and $3.6 \%$ remain indifferent. Sixty point eight percent $(60.8 \%)$ agreed that it is capable of enhancing distance learning. In addition $72.9 \%$ of the sample was of the view that the new format is a more effective and efficient tool for providing more qualitative and sustainable education than the old traditional lecture method (73.8\%) agreed.

While $6.4 \%$ disagreed, other students were motivated to use the new format, because it is an efficient system that is not affected by the challenge of space and infrastructure (66.6\%) agreed, $9.1 \%$ disagreed and $19.6 \%$ were indifference. Thus, WBLS was accepted more by students simply because of their perceived usefulness.

On the behavioural intention of the students to use the Web-based learning format, find the results of the data collected in respect of the objective (see Table 3). The students were unanimous in their acceptance to use the web-based Learning System, $74.05 \%$ were favourably disposed to it.In addition $71 \%$ of the students accepted to use the format because of the interest developed as a result of public enlightenment campaign at motivating students to use the new learning devices.

In summary, $81.4 \%$ of the students accepted the usage of the new format. Those who were not in support probably belong to the group who are resistant to innovation, and those who are ignorant of the pedagogical advantages of the new system. It may also be due to students' indifference and lack of appropriate ICT skills.This is reflected in the data collected with respect to the problems/challenges encountered by students in utilizing the new innovative strategy (See Table 4,Appendix).

\section{Conclusion}

Based on the findings of the study, the following conclusions are made: that the students were motivated in using the new innovative strategy especially the e-learning format but the challenges of internet accessibility and epileptic power supply made them to prefer other forms of technology support learning system like multi-media presentation, tele-lecture and blended learning to e-learning format that is internet based. In addition, other factors that motivated the students to accepting this new strategy include the fact that it is user friendly, the public enlightenment about its advantages, capacity for open-distance learning, its ability to decongest large crowded classroom and enhance quality teaching and learning.

\section{Recommendation}

In order to resolve the challenges and to ensure sustainable education, the issue of proper funding is essential. Since government subvention is not enough even to pay staff salaries not to talk of capital projects, the University should liase with corporate organization and industries to contribute to the growth and development of the education sectors. The problem of epileptic power supply should be addressed. The power sector should be deregulated. We should look for alternative source of power supply like solar power. More attention should be given to Distance Education by concentrating more on skill acquisition and entrepreneurial education as a way to reducing the high-rate of youth unemployment. International and transnational collaborations should be encouraged with emphasis on training and opening up more job facilities for the unemployed.

\section{References}

Ajayi,T. (1996). Obafemi Awolowo University, Ile-Ife Net Work (OAUNET). Computer Center,OAU Ife,Nigeria. p12.

Egwu, S.O. (2009). Road map to the education sector. Federal Ministry of Education, Abuja. p35. 
Faborode, M.O. (2009). Welcome to Obafemi Awolowo University, Ile-Ife, Nigeria's leading ICT University.Published by the Vice-Chancellor OAU Ife, p35.

Impact. (2009). An Appraisal of Carnegie Cooperation of New York grants at Obafemi Awolowo University, Ile-Ife. Vice-Chancellor's Office, Ile-Ife, pp28-29.

Monaham, T. (2005). Globalization, technological change and public education. New York, Routledge, Taylor and Francis, p45.

National policy for Information Technology. (2001). Nigeria National Policy for information technology. Federal Ministry of Communication Abuja. [Online] Available: http://IT\%20policy\%20Nigeria(1)pdf (May 20, 2009)

Obafemi Awolowo University, Ile-Ife. (2003). A strategic plan for Obafemi Awolowo University. Compiled by the strategic planning committee under the chairmanship of Prof. R.O. Makanjuola. p5.

OECD. (2007). Glossary of statistical terms Millennium Development Goals, meaning and indicators. [Online] Available: http:stats.oecd.org/glossarydetail.asp?ID=7331 (May 20, 2009)

UNESCO. (1990). World Declaration on Education, Needs and Framework for Action to meet the Basic Learning Needs. Adopted by the World conference on education forum. Dakar, Senegal.

Table 1. Adoption of WBLS among the Students of OAU Ile-Ife

\begin{tabular}{|l|l|l|l|l|l|}
\hline Format Adopted & SA & A & UND & SD & D \\
\hline e-learning & $102(34.8 \%)$ & $106(36 \%)$ & $18(6.1 \%)$ & $12(4.1 \%)$ & $54(18.4 \%)$ \\
\hline Multi-media learning & $104(35.7 \%)$ & $4(32.3 \%)$ & $20(6.9 \%)$ & $60(20.6 \%)$ & $13(4.5 \%)$ \\
\hline Tele-lecture & $105(36.3 \%)$ & $94(32.3 \%)$ & $59(20.3 \%)$ & $22(7.5 \%)$ & $12(4.1 \%)$ \\
\hline Blended Technology & $103(35.3 \%)$ & $97(33.3 \%)$ & $59(20.3 \%)$ & $13(4.5 \%)$ & $19(6.5 \%)$ \\
\hline $\begin{array}{l}\text { CD Rom/Video Taped } \\
\text { instruction }\end{array}$ & $62(21.1 \%)$ & $166(56.6 \%)$ & $58(19.7 \%)$ & $3(1.10 \%)$ & $5(1.7 \%)$ \\
\hline
\end{tabular}

Table 2. The motivating factors for using WBLS

\begin{tabular}{|l|l|l|l|l|l|}
\hline Reasons & SA & A & UND & SD & D \\
\hline $\begin{array}{l}\text { Ability to decongest large } \\
\text { class }\end{array}$ & $108(36.3 \%)$ & $172(56.2 \%)$ & $11(3.6 \%)$ & $2(.7 \%)$ & $13(4.1 \%)$ \\
\hline $\begin{array}{l}\text { Capacity for Open Distance } \\
\text { Learning }\end{array}$ & $88(28.8 \%)$ & $98(32.0 \%)$ & $42(13.7 \%)$ & $12(3.9)$ & $14(4.6)$ \\
\hline $\begin{array}{l}\text { Improve teaching and } \\
\text { learning }\end{array}$ & $10(35.6)$ & $114(37.3 \%)$ & $23(7.5 \%)$ & $9(2.9 \%)$ & $10(3.3 \%)$ \\
\hline $\begin{array}{l}\text { Solve the challenges of space } \\
\text { and infrastructure }\end{array}$ & $104(35.9 \%)$ & $94(30.7 \%)$ & $60(19.6 \%)$ & $13(4.2 \%)$ & $15(4.9 \%)$ \\
\hline
\end{tabular}

Table 3. Behavioural intention of student to use the WBLS

\begin{tabular}{|l|l|l|l|l|l|}
\hline & SA & A & UND & SD & D \\
\hline $\begin{array}{l}\text { I am favourably disposed to } \\
\text { using WBLS }\end{array}$ & $92(30.01 \%)$ & $136(44.4 \%)$ & $58(18.96 \%)$ & $15(4.9 \%)$ & $7(2.28 \%)$ \\
\hline $\begin{array}{l}\text { I am motivated by the public } \\
\text { enlightenment programme }\end{array}$ & $159(51.9 \%)$ & $60(19.6 \%)$ & $62(20.3 \%)$ & $19(6.21 \%)$ & $8(2.61 \%)$ \\
\hline $\begin{array}{l}\text { I accept to use it because it is } \\
\text { better and more user friendly }\end{array}$ & $172(56.2 \%)$ & $108(35.2 \%)$ & $13(4.2 \%)$ & $11(3.5 \%)$ & $2(0.65 \%)$ \\
\hline
\end{tabular}

Table 4. Ranking of the problems and challenges students encountered using Freidman Test

\begin{tabular}{|l|l|}
\hline Challenges & Mean Ranking $(\bar{*})$ \\
\hline Resistance from students/staff & 4.85 \\
\hline Poor maintenance culture & 4.71 \\
\hline $\begin{array}{l}\text { Lack of awareness of the pedagogical } \\
\text { advantages }\end{array}$ & 4.65 \\
\hline Inadequate facilities & 4.49 \\
\hline Students indifference/negative attitude & 4.41 \\
\hline Lack of faculty support & 4.24 \\
\hline
\end{tabular}

